\title{
PREVALENCE OF ECTOPARASITES IN SMALL RUMINANTS (CASE: AFAR REGION OF ETHIOPIA)
}

\author{
Endris FEKI ${ }^{1 \otimes} \bowtie$, Solomon GEBRE 2 , Ayalew SHUMET ${ }^{3}$, Yimer GOBENA ${ }^{3}$, Hussen MOHAMMED ${ }^{3}$ and Ashenafi EBREGERGIOUS ${ }^{3}$ \\ ${ }_{1}^{1}$ Afar Pastoral and Agro-pastoral Research Institute, Afar, Semera, P.O.Box 16, Ethiopia \\ ${ }^{2}$ National Animal Health Diagnostic and Investigation Centre (NADIC), Sebeta, P.O. Box 4, Ethiopia \\ ${ }^{3}$ Samara Regional Veterinary Laboratory, Afar, Semera, P.O. Box 33, Ethiopia \\ Email: endrisf@yahoo.com \\ Supporting Information
}

\begin{abstract}
A study was conducted from August 2016 to November 2017 to investigate the prevalance of major ectoparasites of small ruminant and associated risk factors in fourteen districts found in the three Zones of Afar Regional State of Ethiopia. A total of $\mathbf{5 3 7 6}$ small ruminants were examined to determine the prevalence of ectoparasites, includes 3696 goats and 1680 sheep. 1443 (39.00\%) goats and 839 (49.90\%) sheep were found infested with different ectoparasites. The result of the study showed that statically significant difference was found between species of sheep and goats in related to ectoparasite infestation. The overall prevalence of ectoparasite indiocates that $2282(42.45 \%)$ small ruminants were infested by ectoparasites. The most common ectoparasites encountered in order of their predominance were 1968 (36.6\%), 155 (2.88\%), 105 (1.95\%) and $54(0.56 \%)$ ticks, mange mites, lice and flea infestation, respectively. In the present study, five genera of ticks (Rhipicephalus, Hyalomma, Amblyomma and Boophilus), two genera of lice (Linognathus and Damalina) three genera of mites (Sarcoptes, Demodex and Psoroptes), and one genera of flea ctenocephalides were identified on the study animals. Rhipicephalus, Hylomma, Boophilus, Ambylomma was identified as the predominant genera. The prevalence of ectoparasite infestation for different age groups, sex and body condition score were found to vary significantly. In conclusion, among ectoparasites species recorded in the area ticks was found to be highly prevalent in sheep and goats. Tick was predominant followed by mite, lice and flea. The present study revealed an overall ectoparasite prevalence of $2282(42.45 \%)$ in both small ruminant species. Of this, 839 $(49.9 \%)$ and 1443 (39\%) was in sheep and goats, respectively. It also revealed that ticks, mites, lice and fleas are common ectoparasites in the study area. to reduce high prevalence of ectoparasites and their impact on the productivity in small ruminants requires immediate attention, control interventions.
\end{abstract}

Keywords: Ectoparasite, Ethiopia, Prevalence, Ruminant, Ticks.

\section{INTRODUCTION}

In Ethiopia, sheep and goats contribute a substantial proportion of the nation's meat supply and milk. The total numbers of sheep and goats in Ethiopia are estimated about 25.5 and 23.4 million respectively (CSA, 2003). Sheep and goats constitute about $30 \%$ of the total livestock population of the country. Gryscels and Anderson (1993) and are among important contributors to food production in Ethiopia, providing $35 \%$ of meat consumption and $14 \%$ of milk consumption (Asfaw et al., 1998).

Small ruminants are source of income for agricultural community and are also one of Ethiopia's major sources of foreign currency through exportation of live animals, meat and skin (Dessie et al, 2010; Mekuria et al., 2018). However in Ethiopia, contribution of sheep and goats to food production, rural and export income are far below the expected potential. This is because small ruminant production in Ethiopia is constrained by the compound effects of diseases, poor feeding and poor management (Kassa, 2005 and Ayele et al, 2003). Ecto-parasites including ticks, lice, mites etc. play an important role in the transmission of certain diseases (Mohd Zain et al., 2015). Infested animals scratch, rub and bite the affected areas and this end up with skin damage (Seyoum et al., 2015). Moreover, infected ruminants are the most important vectors of protozoan, bacterial, viral and rickettsial diseases (Radostits et al, 2007; Rhabari et al, 2009 and Stuchin et al., 2016).

The increasing severity and periodic rapid spread of the ecto-parasites and skin diseases in the Afar Region demanded that the different institutes to conduct a survey to characterize the true status of ecto-parasites and skin diseases problem and recommend possible control measures: Therefore, the objective of this study was:

- To identify different types of ecto-parasites and associated risk factors in small ruminants.

- To determine the prevalence ecto-parasites in sheep and goats.

- To recommend possible control and prevention measures of ecto-parasites in the region (Radostits et al, 2007; Rhabari et al., 2009 and Stuchin et al., 2016).

So, aim of present study was investigating the prevalance of major ectoparasites of small ruminant and associated risk factors in fourteen districts found in the three Zones of Afar Regional State of Ethiopia. 


\section{MATERIALS AND METHODS}

\section{Study areas}

The study was carried out in fourteen districts selected from zone one, four and five of Afar regional state, namely; Five districts of Zone 1 (AwsiRasu) namely (Afambo, Chifra, Ayssaita, Dubti, Mile), four districts of Zone 5 (HariRasu), (Telalak, Dewe, Hadalella \& Dalifage) and Five districts of Zone 4 (FantenaRasu), (Golina, Awra, Ewa, Yalo \& Teru) were selected for this study. The livestock population in the Afar region estimated at 3.6 million cattle, 2 million sheep, 3 million goats, 0.9 million camels and 0.2 million equines (ERIPAE, 2000). The Afar National Regional State is characterized by an arid and semi-arid climate with low and erratic rainfall. The altitude of the region ranges from $120 \mathrm{~m}$ below sea level to $1500 \mathrm{~m}$ above sea level. Temperatures vary from $20^{\circ} \mathrm{C}$ in higher elevations to $48^{\circ} \mathrm{C}$ in lower elevations. Rainfall is bi-modal throughout the region with a mean annual rainfall below $500 \mathrm{~mm}$ in the semi-arid western escarpments and decreasing to $150 \mathrm{~mm}$ in the arid zones to the east. The production system of the Afar region is dominated by pastoralist $(90 \%)$ from which agro-pastoralist $(10 \%)$ is now emerging following some permanent and temporary rivers on which small scale irrigation is developed. The season are traditionally classified as kerma (JulySeptember), which is the long rainy season; sugum (March-April), which is the short rainy season; hagai (May-June) which is the hot dry spell; and gilal (October-February) which is the cool season. Gilal is sometimes interrupted by rains in January and February.

\section{Animals and sampling}

A cross-sectional study was used to investigate the occurrence of ecto-parasites in sheep, goats and associated risk factors. The study was conducted from August-2016 to November-2017, from the three zonal administrations 14 /fourteen districts/were selected for this study. The study districts selected based on the inclusion criteria on the high sheep and goats population, extent of parasite infection and infestation, accessibility of their Peasant associations and willingness of the pastoralists to participate in the survey. The studied animals were randomly selected using a systematic sampling technique from traditionally managed sheep and goats populations in the respective districts. The studied population was indigenous breed of sheep and goats kept under pastoral type of production which allows free grazing, usually mixed with other animals.

\section{Sample size determination}

Sample size was determined as described by Thrusfield (2005). Accordingly, $50 \%$ expected prevalence of ectoparasites infestations in each study agro-ecology, $5 \%$ acceptable error and $95 \%$ confidence level was applied to determine the sample size of study sheep and goats in each study agro-ecology.

$$
\mathrm{n}=\frac{1.96^{2} \text { pexp (1-pexp) }}{\mathrm{d}^{2}}
$$

Where $n=$ sample size, $d=$ desired absolute precision $(0.05), P_{e x}=$ expected prevalence $(50 \%)$, thus the desired sample size for $P_{e x}=0.05$ is $n=384$. Sampling was 384 from each district. Proportionally distributed based on the total large ruminant population in the study districts and PAs.

\section{Data collection}

Data was collected such as species type, age, sex, and body condition score. The ages of the animals were estimated using the definition described by Aiello and Mays (1998). When lambs and kids were less than 6 month old, they were considered as "young animals" whereas when small ruminants were more than 6 month old they were included in the "adult" group. And also the age determine by using dental formula. Body condition scores will be determined by modifying the system of Gatenby (2002) animals either poor or good body condition.

\section{Sample collection and handling procedure}

During clinical examination the skin will be palpated across all parts of the animal for the presence of ectoparasites, and gross lesions suggestive of a clinical form of parasitic infestations. Animals found infested will be considered positive. From sheep and goats ticks, lice and fleas were collected with forceps from their predilection sites of attachment. The ticks were removed from the host skins whilst retaining their mouth parts for identification using forceps. Coat brushing techniques was used for collection of lice. They will be placed in labeled universal bottles containing $70 \%$ ethanol and identified under a stereoscopic microscope according to the descriptions of ticks (Walker et al., 2003). When skin lesions were evidenced skin scraping from suspected cases of mange were collected and preserved in $10 \%$ formalin. Mite identification was made according to Wall and Shearer (2001) and Taylor et al. (2007).

\section{Ethical Regulation}

Handling, sampling and all of animal related cantacts were in according to ethical regulation standart of Pastoral and Agro-pastoral Research Institute of Ethiopia.

\section{Statistical analysis}

The collected data were entered in Microsoft excel. An intercooled Stata 7 software (Stata Corporation, 2001) statistical program was employed for the data analysis. The prevalence of tick was determined by dividing the number of 
positive samples by the total sample size, and was expressed as percentage. Chi-square ( $X 2)$ test was used to assess if there was a statistically significant difference in tick infestation with in different groups. For this analysis P-value less than 0.05 was considered significant.

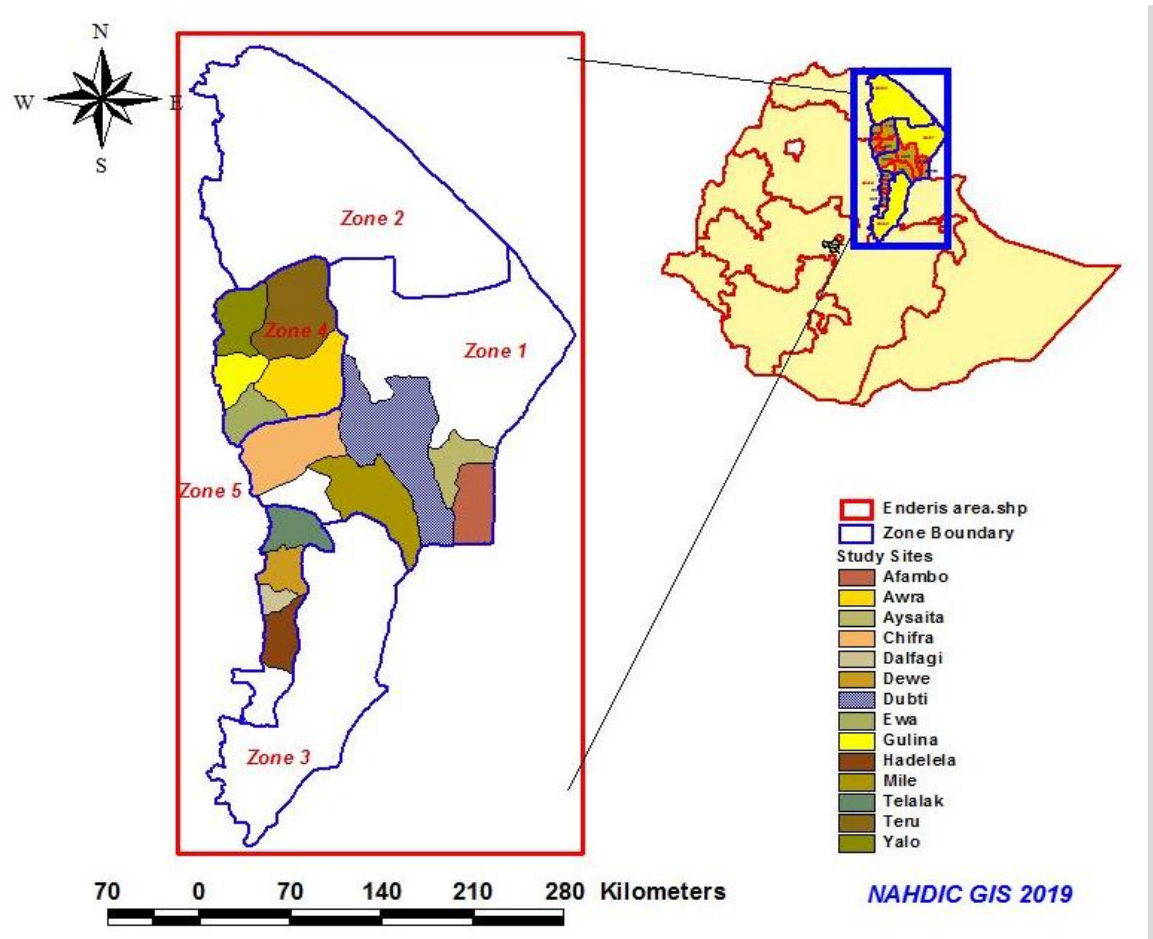

Figure 1 - Map of study districts in the region. * National Animal Health Diagnostic and Investigation Centre (NADIC) GIS, 2019

\section{RESULTS and DISCUSSION}

\section{Prevalence of ecto-parasites disease}

A total of 5376 small ruminants were examined to determine the prevalence of ecto-parasites infestation in 14 districts of Afar region. Of these, 2282 (42.45\%) were infested by ecto-parasites identified. The overall prevalence of ectoparasites was higher in sheep than goats (Table 1). Ticks were identified as the predominant ectoparasites in small ruminants followed by mite, lice and Flea infestations (Table 2). The total number of ectoparasites collected were 2282 (42.45\%). Of these 1968 (36.6\%), 155 (2.88\%), 105 (1.95\%) and 54 (0.56\%) accounted for tick, mange mites, lice and flea infestation, respectively (Table 2 ).

\section{Table 1 - Prevalence of ectoparasites in small ruminants of Afar region, Ethiopia}

\begin{tabular}{|c|c|c|c|c|c|c|c|}
\hline \multirow{2}{*}{ Characteristics } & & \multicolumn{2}{|c|}{ Parasites states of the area } & \multirow{2}{*}{ COR (95\% Cl) } & \multirow{2}{*}{ P-value } & \multirow{2}{*}{ AOR (95\% Cl) } & \multirow{2}{*}{$\begin{array}{c}\mathrm{P}- \\
\text { value }\end{array}$} \\
\hline & & Positive & Negative & & & & \\
\hline \multirow{2}{*}{ Animals } & Goats & 1443(39\%) & $2253(61 \%)$ & 1 & \multirow{2}{*}{0.0001} & 1 & \multirow{2}{*}{0.001} \\
\hline & Sheep & $839(49.9 \%)$ & $841(50.1 \%)$ & $1.558(1.387,1.750)$ & & $0.642(0.572,0.721)$ & \\
\hline
\end{tabular}

Table 2 - Percentage of ectoparasites prevalence found in small ruminants in the Afar region, Ethiopia

\begin{tabular}{lcc} 
Ectoparasites & No. of positive shoats & $\%$ \\
\hline Tick & 1968 & 36.61 \\
Mange & 155 & 2.88 \\
Lice & 105 & 1.95 \\
Flea & 54 & 0.56 \\
Total ecoparasites count & 2282 & 42.41 \\
\hline
\end{tabular}

\section{Prevalence of ectoparasites by Genus level}

In the present study four genera of ticks (Rhipicephalus, Hyalomma, Boophilus and Amblyomma, three genera of mites (sarcoptes, Demodex and Psoroptes), two genera lice (Linognathus and Damalina) and one genera of flea Ctenocephalides were identified. Of the total of 3696 goats and 1680 sheep examined for the infestation of ticks, mite, lice and flea; 1968 (36.61\%), 155 (2.88\%), 105 (1.95\%), 54(0.56\%) of shoats were infested with these ectoparasites respectively (Table 3). 
Prevalence of ecto-parasites at species level

Nine species of ticks which belong to the five genera were identified. Rhipicephaluspulchellus, 599 (11.14\%) Rhipicephalus evertsi, 495 (9.21\%) and Rhipicephalus Pravus, 191 (3.55\%) were the dominant ones. Mange mites genera identified were; Sarcoptes 77 (1.43\%), Psoroptes 48 (0.89\%) and Demodex 30 (0.56\%). The most prevalent lice species found on animals were Damalina ovis, 33 (1.96\%), Linognathus ovis, 20 (1.19\%) on sheep and Linognathus caprae, 28 $(0.76 \%)$ and Damalina caprae, $24(0.65 \%)$ on goats. The overall prevalence of Ctenocephalidia was $22(0.48 \%)$ in sheep and goats (Table 4).

\begin{tabular}{|c|c|c|c|c|}
\hline \multirow{2}{*}{ Types } & \multirow{2}{*}{ Genus } & Goat 3696 & Sheep1680 & Shoat 5376 \\
\hline & & Prevalence & Prevalence & Prevalence \\
\hline \multirow{5}{*}{ Ticks } & Rhipicephalus & $918(23.94 \%)$ & $528(31.43 \%)$ & $1446(26.90 \%)$ \\
\hline & Hyalomma & 126 (3.41 \%) & 72 (3.92\%) & $198(3.68 \%)$ \\
\hline & Boophilus & 109 (2.95\%) & 56 (3.33\%) & $165(3.07 \%)$ \\
\hline & Amblyomma & 97 (2.62\%) & 62 (3.69\%) & $159(2.96 \%)$ \\
\hline & Sub total & $1250(33.82 \%)$ & 718 (42.74\%) & 1968 (36.61\%) \\
\hline \multirow{4}{*}{ Mite } & Sarcoptes & $67(1.81 \%)$ & $10(0.60 \%)$ & $77(1.43 \%)$ \\
\hline & Psoroptes & $16(0.43 \%)$ & 32 (1.90\%) & 48 (0.89\%) \\
\hline & Demodex & 26 (0.70\%) & 4 (0.24\%) & 30 (0.56\%) \\
\hline & Sub total & 109 (2.95\%) & $46(2.74 \%)$ & $155(2.88 \%)$ \\
\hline \multirow{3}{*}{ Lice } & Damalinia & $24(0.65 \%)$ & $33(1.96 \%)$ & $57(1.06 \%)$ \\
\hline & Linognathus & $28(0.76 \%)$ & 20 (1.19\%) & $48(0.89 \%)$ \\
\hline & Sub total & 52 (1.41\%) & 53 (3.15\%) & 105 (1.95\%) \\
\hline \multirow{3}{*}{ Flea } & Ctenocephalides & $32(0.60 \%)$ & $22(0.48 \%)$ & 54 (0.56\%) \\
\hline & Sub total & $32(0.60 \%)$ & $22(0.48 \%)$ & 54 (0.56\%) \\
\hline & Total & $1443(39.00 \%)$ & 839 (49.90\%) & 2282 (42.45\%) \\
\hline
\end{tabular}

\section{Table 4- Prevalence of tick species in small ruminants of Afar region, Ethipia}

\begin{tabular}{|c|c|c|c|c|}
\hline \multirow{2}{*}{\multicolumn{2}{|c|}{ Genera and species of ecto-parasites }} & Goat 3697 & Sheep 1679 & Shoats 5376 \\
\hline & & Prevalence & Prevalence & Prevalence \\
\hline \multirow{5}{*}{ Rhipicephalus } & Pulchellus & $386(10.44 \%)$ & $213(12.68 \%)$ & 599 (11.14\%) \\
\hline & Evertsi evertsi & 297 (8.04\%) & $198(11.79 \%)$ & 495 (9.21\%) \\
\hline & Pravus & $131(3.54 \%)$ & $60(3.57 \%)$ & $191(3.55 \%)$ \\
\hline & Praetexatus & $104(2.81 \%)$ & 57 (3.39\%) & $161(2.99 \%)$ \\
\hline & Over all & 918 (24.84\%) & $528(31.43 \%)$ & $1446(26.90 \%)$ \\
\hline \multirow{4}{*}{ Hyalomma } & Truncatum & $72(1.95 \%)$ & $42(2.50 \%)$ & $114(2.12 \%)$ \\
\hline & Dromedarii & $39(1.06 \%)$ & $17(1.01 \%)$ & $56(1.04 \%)$ \\
\hline & Anatolicum anatolicum & $15(0.41 \%)$ & $13(0.77 \%)$ & $28(0.52 \%)$ \\
\hline & Over all & $126(3.41 \%)$ & $72(3.92 \%)$ & $198(3.68 \%)$ \\
\hline \multirow{2}{*}{ Boophilus } & Decoloratus & $109(2.95 \%)$ & $56(3.33 \%)$ & $165(3.07 \%)$ \\
\hline & Over all & $109(2.95 \%)$ & $56(3.33 \%)$ & $165(3.07 \%)$ \\
\hline \multirow{3}{*}{ Amblyomma } & Gemma & $80(2.16 \%)$ & 54 (3.21\%) & $134(2.49 \%)$ \\
\hline & Variegatum & $17(0.46 \%)$ & $8(0.48 \%)$ & $25(0.47 \%)$ \\
\hline & Over all & $97(2.62 \%)$ & $62(3.69 \%)$ & $159(2.96 \%)$ \\
\hline
\end{tabular}

Prevalence of ectoparasites in sheep and goats by different host related factors

An effort was made to determine the prevalence of ectoparasites in relation to different host factors such as sex, age, and body condition scores. The result is presented in table 5 . In regard to sex, male small ruminants were more infested (64\%) than females (23.6\%) and this was found to be statistically significant (Table 5). The result shows statically different $(P<0.05)$. The prevalence of infestation with different ectoparasites age and body condition score groups. The study revealed a higher prevalence in male, adult age groups and poor body condition score animals higher than good body condition (Table 5).

Table 5 - Prevalence of ectoparasites in sheep and goats by different host related factors.

\begin{tabular}{|c|c|c|c|c|c|}
\hline \multirow{2}{*}{\multicolumn{2}{|c|}{ Characteristics }} & \multicolumn{2}{|c|}{ Status of parasites } & \multirow{2}{*}{ COR $(95 \% \mathrm{Cl})$} & \multirow{2}{*}{ p-value } \\
\hline & & Positive & Negative & & \\
\hline \multirow[b]{2}{*}{ Sex } & Female & $678(23.6 \%)$ & $2191(76.4 \%)$ & 1 & \multirow{2}{*}{$<0.001{ }^{a}$} \\
\hline & Male & $1604(64 \%)$ & $903(36 \%)$ & $5.740(5.098,6.463)$ & \\
\hline \multirow{2}{*}{ Age } & Young & $500(30 \%)$ & $1168(70 \%)$ & 1 & \multirow{2}{*}{$<0.001$} \\
\hline & Old & $1782(48.1 \%)$ & 1926 (51.9\%) & $2.161(1.911,2.444)$ & \\
\hline \multirow{2}{*}{ BCS } & Poor & 2244 (90.9\%) & 225 (9.1\%) & 1 & \multirow{2}{*}{$<0.001{ }^{a}$} \\
\hline & Good & $38(1.3 \%)$ & 2869 (98.7\%) & $0.001(0.001,0.002)$ & \\
\hline
\end{tabular}


A total of 3697 goats and 1679 sheep were examined for the infestation of ectoparasites. The overall prevalence of ectoparasite infestation in the present study was found to be 2282 (42.45\%). The present finding of ectoparasites in the study area was lower than the prevalence study reported from Zone four of Afar region by Fikre et al. (2015), with the prevalence of $94.62 \%$ and $91.86 \%$ in sheep and goats respectively. Bekele et al. (2011) reported the prevalence of 99.38\% and $96.92 \%$ in sheep and goats respectively in Wolmera districts of Oromia region central Ethiopia; Tewodros et al (2012) stated prevalence of $\mathbf{8 0 . 9 7 \%}$ in sheep and $\mathbf{7 2 . 0 7 \%}$ in goats around Gonder town, Ethiopia. Our findings showed higher than the result explained by Teshome (2002) that stated the prevalence of $23.8 \%$ in sheep and $16 \%$ in goats and 15.41\% and Yacob et al. (2008). In addition the present study revealed that there is a significant variation in the prevalence of ectoparasites among the animal species, sex of animals, age groups and body conditions of the animals (Table 1, 5 and 6). The rates of infection in this survey were relatively more in sheep (49.9\%) than goats (39.0\%) which agree with a study conducted by Yacob et al. (2008) that in Wolaita Soddo region reported that the rate of infestation by ectoparasites higher in sheep than goats $68.7 \%$ and $28.4 \%$, respectively. Similarly also, the host differences reported in present region by Fikre et al. (2015), that is (94.62\%) sheep and (91.86\%) goats were found infested with ectoparasites. But, Due to this goats appeared to be significantly more resistant than sheep. The result is in goat lower because of their self-grooming, licking, scratching, rubbing and grazing behaviors, which would contribute to rapid ectoparasite elimination, management practice and in the environmental conditions.

These study shows that ticks, mite, lice, flea; 1968 (36.61\%), 155 (2.88\%), 105 (1.95\%), 54(0.56\%) of shoats were infested with above-mentioned of these ectoparasites, respectively. Ticks were found to be the most prevalent ectoparasites in both sheep and goats throughout the study areas. The present result indicates that infestation still need more efforts to achieve expected control result and reduction of impact excreted by ticks but on the other hand others ectoparasite species like mite, lice and flea infestation result is reduced on the present study result. A relative low prevalence of tick infestation (31.8\%) in sheep and (18.6\%) in goats were reported by Teshome (1994) and were as low result were reported by Zelalem (1994), $23.8 \%$ in sheep $16 \%$ in goats from the Sidama Zone in Southern Ethiopia.

Different study indicated that ectoparasites affected both sexes. In this study, a higher prevalence of ectoparasite infection was in male sex group $(64 \%)$ than female sex group $(23.6 \%)$ and this was significantly $(P<0.05)$ different $($ Table 5). Similarly, Tewodros (2012) reported higher ectoparasite prevalence was observed in male than female and also the result collaborated with those reported by Abebe et al. (2011) and Sertse and Wossene A. (2007). However, dissimilar to the previous reports of Yacob et al. (2008), was also noticed that females were significantly more frequently affected than males $(75.45 \%$ vs. $61.54 \%)$ : The variation compare with our findings is due to areas of people use one male for many flocks of sheep and goats in the areas, due to this the males has opportunity to frequent contact with infested goats and sheep.

In present study the prevalence of ectoparasites of adult age group (48.1\%) was higher than young age group (30\%) (Table 5). The result was significant association $(P<0.05)$. This finding was similar with Tefera $(2004)$ and Fikre et al. (2015), with the infection rate of $51.05 \%$ and $54.2 \%$ in young and adult age, and also the prevalence of ectoparasite was higher in adult $(96.91 \%$ in sheep, $93.83 \%$ in goat) than young, and (88.52\% in sheep, $86.25 \%$ in goat) respectively. The result dissimilar with the result of Yakob et al. (2008), that reported the prevalence of $53 \%$ and $15 \%$ for adult and young age group small ruminants in Wolaita Sodo, respectively. This is may be due to differences to infection as a result of variation in also the management system where animals are allowed to graze together in communal fields.

Concerning the prevalence of different ectoparasites high infested in poor body conditions than that of good body condition of small ruminants. Our findings showed that the prevalence of poor body condition (90.9\%) and good body condition (1.3\%; Table 5). Present finding is similar with results reported by Madeira et al. (2000), Sertse and Wessene (2007), Mulugata et al. (2010) and Tewodros (2012).

\section{Table 6 - Prevalence of ectoparasites in different districts}

\begin{tabular}{|c|c|c|c|c|c|}
\hline Zone & Districts & Positive & Negative & COR (95\%Cl) & p-value \\
\hline \multirow{5}{*}{ Zone 4 (Fantena Rasu) } & Ewa & $188(49.0 \%)$ & $196(51 \%)$ & $1.099(0.828,1.458)$ & $0.516^{a}$ \\
\hline & Awra & $150(39.1 \%)$ & $234(60.9)$ & $0.734(0.551,0.978)$ & $0.035 a$ \\
\hline & Gulina & $147(38.3 \%)$ & $237(61.7 \%)$ & $0.710(0.533,0.947)$ & $0.020 a$ \\
\hline & Yallo & $108(28.1 \%)$ & $276(71.9 \%)$ & $0.448(0.332,0.605)$ & $0.001^{b}$ \\
\hline & Teru & $88(22.9 \%)$ & 296 (77.1\%) & $0.340(0.249,0.465)$ & $0.001^{c}$ \\
\hline \multirow{5}{*}{ Zone 1 (Awsi Rasu) } & Afambo & 155 (40.4\%) & 229 (59.6\%) & $0.775(0.582,1.032)$ & $0.005^{b}$ \\
\hline & Asayta & $179(46.6 \%)$ & 205 (53.4\%) & 1 & $0.000^{d}$ \\
\hline & Dubti & $161(41.9 \%)$ & $223(58.1 \%)$ & $0.827(0.622,1.100)$ & $0.191^{a}$ \\
\hline & Mille & $138(35.9 \%)$ & $246(64.1 \%)$ & $0.642(0.481,0.858)$ & $0.003^{e}$ \\
\hline & Chifra & $144(37.5 \%)$ & 240 (62.5\%) & $0.687(0.515,0.916)$ & $0.011^{a}$ \\
\hline \multirow{4}{*}{ Zone 5 (Hari Rasu), } & Telalak & $188(49.0 \%)$ & $196(51.0 \%)$ & $1.099(0.828,1.458)$ & $0.516^{a}$ \\
\hline & Dewe & $250(65.1 \%)$ & $134(34.9 \%)$ & $2.137(1.598,2.856)$ & $0.000^{b}$ \\
\hline & Dalifage & $197(51.3 \%)$ & $187(48.7 \%)$ & $1.206(0.909,1.602)$ & $0.194^{a}$ \\
\hline & Hadelela & $189(49.2 \%)$ & $195(50.8 \%)$ & $1.110(0.836,1.473)$ & $0.470^{a}$ \\
\hline
\end{tabular}




\section{CONCLUSION}

Its concluded that, among ectoparasites species recorded in the area ticks was found to be highly prevalent in sheep and goats tick was predominant followed by mite, lice and flea. The present study revealed an overall ectoparasite prevalence of $2282(42.45 \%)$ in both small ruminant species. Of this, $839(49.9 \%)$ and $1443(39 \%)$ was in sheep and goats, respectively. It also revealed that ticks, mites, lice and fleas are common ectoparasites in the study area.

It is suggested that, due to this higher economic losses occur through animal deaths and damages of the skin. Hence, the following recommendations are forwarded:

- Treatment campaign needs to cover of all affected areas and population of small ruminants because of free livestock movement in the region for grazing and watering.

- Sustainable veterinary services and improved management practice and well-coordinated control interventions and Strong monitoring and evaluation measures during the control campaign is very essential.

- It is valuable to implement effective Extension services and training programs aiming at awareness creation about the importance and control of ecto-parasites for livestock owners is very important.

- Moreover further epidemiological investigation is needed in the study area.

\section{DECLARATIONS}

Acknowledgements

The authors would like to thank National Animal Health Diagnostic and Investigation Centre (NADIC) for financial support to execute this research work.

\section{Authors' contribution}

All authors contributed equally to this research work. All authors read and approved the final manuscript.

\section{Avallability of data and materials}

Data will be made available up on request of the primary author

\section{Consent to publish}

Not applicable.

\section{Competing interests}

The data can be available to the journal upon request.

\section{Conflict of interest}

The authors declare they have no competing of interests.

\section{REFERENCES}

Abebe R, T.Makelesh, M.Bekele and S.Dessie (2011). Prevalence of small ruminant ectoparasites and associated risk factors in selected districts of Tigray region, Ethiopia. Global Veterinaria, 7(5): 433-437. https://www.idosi.org/gv/GV7(5)11/4.pdf

Aiello S and Mays A (1998). The Merck veterinary manual, 8th ed., Merck and Co, Inc, White house station, NJ. USA, Pp: 131-133. Google Scholar

Asfaw A (1998). The tanning industry, In: lan, B.C. and Bayou, B.(eds.) proceedings of control of sheep and goat skin disease to improve quality of hides and skin, 13-14 Feb. 1998, FAO, Addis Ababa, Ethiopia. Google Scholar

Ayele SW, Assegid MA, Jabbar MM and Belachew H (2003). Livestock marketing in Ethiopia: A review of structure, performance and developing initiatives, working paper No. 52, Addis Ababa, Ethiopia, pp: 1-4. Google Scholar

Bekele J, Tariku M, and Abebe R (2011). External parasites infestation in small ruminants in Wolmera district of Oromia region, central Ethiopia. Journal of Animal and Veterinary Advances, 10: 518-532. Link

CSA (2003). Ethiopian Agricultural Sample Enumeration, 2001/2002; Results at Country level; Statistical report on livestock and farm implements, Part IV. Federal Democratic Republic of Ethiopia: Central Agricultural Census Commission. July 2003. Addis Ababa, Ethiopia. 35-70.

Dessie S, Hailu D and Dereje B (2010). Epidemiological study of small ruminant mange mites in three agro-ecological zones of Wolaita, Southern Ethiopia. Ethiopean Veterinary Journal, 14 (1): 31-38. Available at: https://www.ajol.info/index.php/evj/article/view/63867

ERIPAE (2000).Emergency response interventions in pastoral areas of Ethiopia. Addis Ababa, Ethiopia. AGRIS I Google Scholar

Fikre Z, Hailegebrael B, Muuz G, Ahmed S, Ashenafi G. (2015). Epidemiology of major small ruminant ectoparasites and effectiveness of the control approaches employed in selected pastoral districts of Afar, Northeastern Ethiopia. Journal of Biology Agriculture and Health. 5(14):1-0. Google Scholar

Gatenby MR. (1991). Sheep. In: Coste R, Smith JA, editors. The Tropical Agriculturalist. London: Macmillan and CTA (Wageningen). p. 611. Google Scholar

Gryseels G, Anderson FM. (1983). Studies on Traditional Agricultural Systems, Initial Result, 1977-1980. Research on Farm and Livestock Productivity in Central Ethiopian Highlands, ILCA, Addis Ababa, Ethiopia. 1983: 7-22. Google Scholar

Kassa B (2005). Pre-slaughter defects of hides/skin and intervention options in east Africa: Harnessing the leather industry to benefit the poor. Regional Workshop Proceedings, April 18-20, Addis Ababa, Ethiopia. Google Scholar 
Madeira, N, A.F.T. Amarante and C.R. Padovani (2000). Diversity of ectoparasites in sheep flocks in Sao th Paulo, Brazil. Tropical Animal Health and Production, 32: 225-232. Doi: https://doi.org/10.1023/A:1005227402872

Mekuria SA, Teshager AA, Endeshaw AG, Birhan Atinaw M, and Tesfa Sendeku A (2018). Small ruminant fattening practices in Amhara region, Ethiopia. Agriculture \& Food Security, 7:64. https://doi.org/10.1186/s40066-018-0218-9

Mohd Zain SN, Syed Khalil Amdan SA, Braima KA. et al (2015). Ectoparasites of murids in peninsular Malaysia and their associated diseases. Parasites Vectors, 8: 254 https://doi.org/10.1186/s13071-015-0850-1

Mulugeta Y, Yacob HT and Hagos A (2010). Ectoparasites of small ruminants in three agro-ecological sites of Tigray Region, Ethiopia. Tropical Animal Health and Production, 42: 1219-1224. Doi: https://doi.org/10.1007/s11250-010-9551-0

Radostits OC, Gay KW and Hinchcliffand P.D. Constable (2007). A textbook of the diseases of cattle, sheep, goats, pigs and horses, 10 edition, Suanders, Edinburgh, London, pp: 1585-1612.

Rahbari S, Nabian S and Bahohar A (2009). Some observations on sheep sarcoptic mange in Tehran provinces, Iran. Tropical Animal Health and Production, 41: 397-401. Doi: http://dx.doi.org/10.1007/s11250-008-9203-9

Serste T and Wossene A (2007). A study on ectoparasites of sheep and goats in eastern part of Amhara region, northeast Ethiopia. Small Ruminant Research, 69: 62-67. Doi: http://dx.doi.org/10.1016/i.smallrumres.2005.12.010

Sertse T and Wossene A. (2007). A study on ectoparasites of sheep and goats in eastern part of Amhara region, northeast Ethiopia. Small Ruminant Research. May 1;69(1-3):62-7. https://doi.org/10.1016/j.smallrumres.2005.12.010 I Google Scholar

Seyoum Z, Tadesse T and Addisu, A. (2015). Ectoparasites prevalence in small ruminants in and around sekela, amhara regional state, northwest Ethiopia. Journal of Veterinary Medicine, 2015: 216085. Doi: https://doi.org/10.1155/2015/216085

Stuchin M, Machalaba CC, Karesh WB (2016). Vector-borne diseases: animals and patterns. In: Forum on Microbial Threats; Board on Global Health; Health and Medicine Division; National Academies of Sciences, Engineering, and Medicine. Global Health Impacts of Vector-Borne Diseases: Workshop Summary. Washington (DC): National Academies Press (US); 2016 Sep 21. A5. Available from: https://www.ncbi.nlm.nih.gov/books/NBK390438/

Taylor M, Coop R and Wall R (2007). Veterinary parasitology, $3^{\text {rd }}$ edition by Black well publishing Ltd., UK. 874. Google Scholar

Tefera S (2004). Investigation on ectoparasites of small ruminants in selected sites of Amhara regional state and their impact on the tanning Industry MSc thesis, Addis Ababa University, Faculty of Veterinary Medicine. Google Scholar

Teshome W (2002). Study on skin diseases of small ruminant in Sidama zone, southern Ethiopia', DVM thesis, Faculty of Veterinary Medicine, Addis Ababa University, DebreZeit, Ethiopia. Google Scholar

Tewodros F, Fasil W, Mersha C and Malede B (2012). Prevalence of ectoparasites on small ruminants in and around Gondar town. American-Eurasian Journal of Scientific Research, 7 (3): 106-111. Link

Thrusfield M (2005). Veterinary epidemiology, Third Edition, Blackwell Science Ltd.,UK, 229-245 pp. Google Scholar

Walker A, Bouattour A, Camicas J, Estrada-Pena A, Horak I, Latif A, Pegram R, and Preston P (2003). Ticks of domestic animals in Africa: a guide to identification of species. Bioscience Report. pp. 1-221. Link I Google Scholar

Wall R and Shearer D. (2001). Veterinary ectoparasites biology pathology and control, $2^{\text {nd }}$ edition, Black well science Ltd., UK. 262. Google $\underline{\text { Scholar }}$

Yacob H, AT Yalow and AA, Dink. (2008).Ectoparasite prevalences in sheep and in goats in of and around Wolaitasoddo, Southern Ethiopia. AE Journal of Agriculture and Environmental Sciences, 159: 450-454. Google Scholar

Zelalem T (1994). Survey of mange mites of small Ruminants in Dire Dawa Region, DVM thesis, Faculty of Veterinary Medicine, Addis Ababa University. Google Scholar 